\section{Ultrasonography for Pediatric Central Vein Catheterisation in Inexperienced Hands: A Preliminary Report}

\author{
Ultrasonografi ile Deneyimsiz Ellerde Pediyatrik \\ Santral Ven Kateterizasyonu: Ön Rapor
}

Çiğdem Yıldırım Güçlü ๑ Gülnur Göllü Bahadır ๑

Başak Ceyda Meço $\odot$ Gönül Küçük Erensu ๑ Zekeriyya Alanoğlu ๑ Hüseyin Dindar $\odot$ Neslihan Alkış $\odot$

\section{ABSTRACT}

Objective: Central venous catheterization is a technically difficult procedure in pediatric patients. Ultrasound guidance is becoming popular during the procedure. This study is designed to examine the success rate of ultrasound guidance during internal jugular vein catheterization and factors influencing the success rate in pediatric patients.

Methods: Pediatric patients who underwent central venous catheterization within a period of 12 months were included in the study. After routine anesthesia induction and treatment, patients were positioned for catheterization. Ultrasound-guided catheterization was performed. The performer specified the time to switch cutdown method for catheterization. The patients' demographic characteristics, the performers' experience, cannulation side, number of attempts and complications were recorded. Success was defined as accomplishment of ultrasound-guided catheterization.

Results: In 144 out of 180 patients, cannulation was achieved at the first attempt. Only in 8 catheterization procedures, more than one performer tried to realize the intervention. Nine patients had cutdowns for cannulation, which meant that ultrasound guidance was successful in cannulation of 171 (95\%) patients. Seven cutdowns were performed by the attending physicians, and the other two by residents. Complications as arterial puncture, hemothorax, and pneumothorax were not seen during catheterization.

Conclusion: Ultrasonografi is a very useful tool for catheterization in pediatric patients even in inexperienced hands. Experience is an important factor for improving the success.

Keywords: Ultrasonography, landmark method, catheterization, and pediatric patients

Öz

Amaç: Santral venöz kateterizasyon pediyatrik hastalarda teknik olarak zor bir işlemdir. İşlem sırasında ultrason rehberliği popüler hale gelmektedir. Bu çalışma, pediyatrik hastalarda internal juguler ven kateterizasyonu sırasında ultrason rehberliğinin başarı oranını ve başarı oranını etkileyen faktörleri incelemek için tasarlanmıştır.

Yöntem: 12 ay boyunca santral kateter yerleştirilen pediyatrik hastalar dahil edildi. Rutin anestezi indüksiyonu ve tedavisinden sonra hastalara kateterizasyon için pozisyon verildi. Kateterizasyon ultrason rehberliğinde yapıldı. Ne zaman cut-down'a dönüleceğine kateteri takan kişi karar verdi. Hastaların demografik özellikleri, uygulayıcı deneyimi, kanülasyon tarafı, deneme sayısı ve komplikasyonlar kaydedildi. Başarı, ultrason rehberliği ile kateterizasyon olarak tanımlandı.

Bulgular: ilk girişimde 180 hastanın 144'ünde kanülasyon yapıldı. Yalnızca 8 kateterizasyon işleminde, birden fazla kişi deneme yaptı. Dokuz hastada kanülasyon için cut-down kullanıldı, bu da ultrason rehberliğinin 171 (\%95) hastanın kanülasyonunda başarılı olduğu anlamına geliyor. Dokuz cut-downın 7'si asistanlar, 2'si uzmanlar tarafından gerçekleştirildi. Kateterizasyon sırasında arteriyel ponksiyon, hemotoraks ve pnömotoraks gibi komplikasyon görülmedi.

Sonuç: Ultrasonografi, deneyimsiz ellerde bile pediyatrik hastalarda kateterizasyon için çok yararIı bir araçtır. Deneyim, başarının iyileştirilmesinde önemli bir faktördür.

Anahtar kelimeler: Ultrasonografi, landmark yöntemi, kateterizasyon ve pediyatrik hastalar
Received: 30 September 2019 Accepted: 25 December 2019 Online First: 31 January 2020

Cite as: Yıldırım Guclu C, Gollu Bahadır G, Meco BC, Kucuk Erensu G, Alanoglu Z, Dindar H, Alkıs N. Ultrasound for pediatric central vein catheterisation in inexperienced hands: A preliminary report. JARSS 2020;28(1):26-31.

Çiğdem Yıldırım Güçlü Ankara Üniversitesi Tıp Fakültesi Anesteziyoloji ve Reanimasyon Anabilim Dalı, Ankara, Türkiye

drcigdemyldrm@yahoo.com.tr ORCID: 0000-0002-8416-3418

B.C. Meco 0000-0003-2951-9634

Z. Alanoğlu 0000-0003-4967-5829 N. Alkış 0000-0003-0469-2318 Ankara Üniversitesi Tıp Fakültesi Anesteziyoloji ve Reanimasyon Anabilim Dalı, Ankara, Türkiye

G. Göllü Bahadır 0000-0001-8163-2226

G. Küçük Erensu 0000-0002-3510-8789 H. Dindar 0000-0001-7149-9273 Ankara Üniversitesi Tıp Fakültesi, Çocuk Cerrahisi Anabilim Dalı, Ankara, Türkiye 


\section{INTRODUCTION}

Opening a central venous access may be essential in pediatric patients for the administration of fluid, blood product (s), medications, parenteral nutrition, renal replacement therapy and hemodynamic monitoring. Achievement of a central venous access in pediatric population can be challenging. Failure rates in pediatric patients, range from $5 \%$ to $19 \%$, with reported complication rates varying from $2.5 \%$ to $22 \%^{(1,2)}$. Complications related to realization of central venous access include; arterial puncture, nerve injury, pneumothorax, thrombosis, hematoma and even death ${ }^{(3)}$.

Central venous catheter placement is technically difficult in pediatric patients because of anatomic variations due to smaller size of the patient. The landmark technique has been the standard approach for many years. As compared to landmark method; in pediatric patients the use of ultrasonography (US) has been associated with an increased success rate, decreased operation time, reduced number of attempts, and decreased number of carotid artery punctures ${ }^{(4-7)}$. Failure rates at first attempt have been documented as $60 \%$ in pediatric patients ${ }^{(7,8)}$.

Ultrasound-guided internal jugular vein cannulation has found to be safer and more successful than "landmark technique" in pediatric patients ${ }^{(9,10)}$. In 2001 Agency for Healthcare Research and Quality reported that ultrasound-guided central venous catheter placement as one of the top 11 highly-proven patient safety practices ${ }^{(11)}$. However, ultrasound guidance is still found to be limited in use because of the time delay during procedure ${ }^{(12)}$.

There are many factors that affect the success rate and occurrence of complications including patients' size, site of cannulation, operator's experience, previous cannulations, and vascular anomalies. This study is designed to examine the success rate of ultrasound guidance during internal jugular vein catheterization and factors influencing the success rate in pediatric patients.

\section{MATERIAL and METHODS}

Following ethics committee approval (13968;
13.03.2014), pediatric patients who underwent central venous catheterization within a period of 12 months were included in the study. Informed parental consent was obtained in each case. Inclusion criteria were; ASA I-III, patients aged $>1$ month, central venous catheterization indicated for several reasons (fluid replacement, medication, feeding). Exclusion criteria were; parental refusal, and $<1$ month of age.

The patients were taken into operating room and routine monitorisation applied for each patient. Following induction of anesthesia with either inhalational or intravenous agents, airway was secured using laryngeal mask, tracheal tube or tracheostomy cannula. Anesthesia was maintained using sevoflurane $2-3 \%$ in an oxygen/nitrous oxide mixture.

The patients were placed in supine position with a shallow pillow under their shoulders. The pillow provides about $150^{\circ}$ of neck extension and adjusting the table to Trendelenburg position achieves effective venous filling. Then the head is rotated to the contralateral side of cannulation to provide space for handling and stretching of the veins. After skin preparation for sterile procedure, real-time $2 \mathrm{D}$ ultrasound machine, Venue 40 (General Electric Company ${ }^{\circledR}$, Wauwatosa, WI, USA) with a 12L-SC linear probe was enclosed in a telescopically folded sterile sheath. The performer placed the probe on the neck perpendicular to the skin, lateral to the trachea and superior to the clavicle. The internal jugular vein lies laterally to the carotid artery, into the center of the triangle formed by the two lower heads of the sternocleidomastoid muscle and the clavicle. The carotid artery and internal jugular vein could be distinguished by their characteristics by using out-of-plane approach, so the veins were visualized in short axis. When the best image of the jugular vein was obtained, the middle point of the probe was aligned on the jugular vein. Following identification of the ideal puncture site, the needle was inserted from the midpoint of the probe. When the flashback into the syringe was observed, the guide wire was inserted through the needle. After confirming the position of the guide wire by fluoroscopy, cannulation was completed by using Seldinger's technique. Fluoroscopy was used to determine the final position of the catheter tip. Either a 4 or $5 \mathrm{Fr}$ double-lumen central venous cat- 
heter (Arrow International ${ }^{\circledR}$, Reading, PA, USA) was used according to patient's age.

The right side was always the index choice for cannulation. After four unsuccessful attempts, the cannulation side was shifted. If the patient had undergone cannulation from the right side before, then left side was used for cannulation as index choice. The performer decided when to use cutdown method. Switching to cutdown method was defined as 'failure of cannulation'.

Age, weight, diagnosis, airway device, history of cannulation, the performer's experience resident or specialist, years of experience, number of attempts, cannulation side, number of cutdowns, duration of surgery, and anesthesia and catheter-related complications were recorded.

Data analysis was performed with statistical software (SPSS for Windows, version 15, SPSS Inc., Chicago, IL, USA). Descriptive statistics of variables with normal distribution were expressed as mean \pm standard deviation and those with abnormal distribution as median (minimum-maximum). The nominal variables were expressed as numbers and percentages (\%). The differences between the mean values were evaluated by t-test, and between median values by Mann-Whitney $U$ test. Nominal variables were evaluated with Pearson $\chi^{2}$ test (chi-square test) or Fisher exact test. Statistical significance was set at $P \leq .05$. According to the statistical power analysis, the results of 172 study patients were within $95 \%$ confidence interval.

\section{RESULTS}

During a 12-month period, 180 central vein catheterization procedures were performed.

Table I. Indications for central vein catheterization

\begin{tabular}{lc}
\hline Indications & Number of patients (\%) \\
\hline Hematologic disorders & $100(\% 55.56)$ \\
Malignancy & $43(\% 23.89)$ \\
Surgery for gastrointestinal pathology & $26(\% 14.44)$ \\
Neurosurgical disorders & $4(\% 2.22)$ \\
Renal insufficiency & $2(\% 1.11)$ \\
Other & $5(\% 2.78)$ \\
\hline
\end{tabular}

Median age of the patients was 36 months (range, 1 month-18 years), and a median weight was $15.5 \mathrm{~kg}$ (range, 1-85 kg). The indications are shown in Table I. Seventeen $(9.4 \%)$ out of all $(n=180)$ patients had more than one diagnosis.

Airway management was performed either by using laryngeal mask airway (LMA) (144/180), endotracheal tube $(35 / 180)$ or via tracheostomy cannula $(1 / 180)$.

The performers were either attending physicians or residents. Ninety-nine (55\%) attending physicians, and $81(45 \%)$ residents performed catheterizations. The median years of experience of attending physicians, and residents were 4 (range, 2 to 5 ) and 3 (range, 1-5) years, respectively.

Table II. Number of attempts

\begin{tabular}{lc}
\hline Number of attempts & Number of patients (\%) \\
\hline 1 & $144(80)$ \\
2 & $23(12.8)$ \\
3 & $6(3.3)$ \\
4 & $5(2.8)$ \\
5 & $2(1.1)$ \\
\hline
\end{tabular}

Venous catheterization was performed successfully in 144 out of 180 patients at first attempt (Table II). Only in 8 patients more than one performer attempted catheterization.

In 9 patients cutdowns were performed for cannulation, which means that US guidance succeeded in cannulation of 171 (95\%) patients. The seven out of nine cutdowns were applied by attending physicians, and others by residents. There was no difference between attending physicians, and residents as for

Table III. The characteristics of the patient who had cut-down for catheterization

\begin{tabular}{lcccc}
\hline $\begin{array}{l}\text { Age } \\
\text { (months) }\end{array}$ & $\begin{array}{c}\text { Weight } \\
(\mathbf{k g})\end{array}$ & Performer & $\begin{array}{c}\text { Performer } \\
\text { experience (years) }\end{array}$ & $\begin{array}{c}\text { Number of } \\
\text { attempts }\end{array}$ \\
\hline 36 & 16 & Attending & 5 & 3 \\
36 & 14 & Resident & 3 & 2 \\
1 & 3 & Attending & 4 & 1 \\
4 & 7 & Attending & 5 & 1 \\
2 & 6 & Attending & 3 & 1 \\
60 & 22 & Resident & 4 & 2 \\
48 & 8 & Attending & 4 & 2 \\
36 & 15 & Attending & 3 & 3 \\
2 & 5 & Attending & 3 & 2 \\
\hline
\end{tabular}


using of the cutdown method ( $p=0.179)$ (Table III). There was a difference between patients who had successful and unsuccessful cannulation in terms of their age and weight. The median age of the patients who had cannulation via cutdown was 0.29 years (0.08-13 min-max) $(p=0.002)$, and the median weight was $5 \mathrm{~kg}(3-15 \mathrm{~min}-\max )(p<0.001)$.

Venous access times differed between attending physicians, and residents. The median access time related to attending physicians' performance (the time between penetration of needle and replacement of catheter) was $15 \mathrm{~min}$ (range, 5-60 min), while it was $20 \mathrm{~min}$ (range, 5-45) for residents $(p=0.021)$ (Table IV).

Table IV. Comparison between attendings and residents

\begin{tabular}{lccc}
\hline & $\begin{array}{c}\text { Attendings } \\
(\mathbf{n}=\mathbf{9 4})\end{array}$ & $\begin{array}{c}\text { Residents } \\
(\mathbf{n}=\mathbf{8 1 )}\end{array}$ & $\mathbf{P}$ \\
\hline Cut-down (n of patient) & $7 / 94$ & $2 / 81$ & 0.179 \\
Time (min) (median, min-max) & $15(5-60)$ & $20(5-45)$ & 0.021 \\
$\begin{array}{l}\text { Experience (year) } \\
\text { Performance ( } \mathrm{n} \text { of patients) }\end{array}$ & $3.93 \pm 0.62$ & $2.78 \pm 0.90$ & $<0.001$ \\
(percentage to total n of & & & \\
patients) & & & \\
\hline
\end{tabular}

There was no complication like arterial puncture, hemothorax, and pneumothorax during catheterizations.

\section{DISCUSSION}

In conclusion, as an outcome of this study, US guidance has significantly achieved meaningful success in internal jugular vein cannulation in pediatric patients and the performers' experience is an important factor during this procedure. There is a reverse proportion between years of experience and number of cutdowns performed.

Central vein catheterization is generally performed to infuse drugs (especially chemotherapeutics) and fluids in pediatric patients. The practice of US during central venous catheterization was described in 1990 's and has gained popularity over years ${ }^{(13)}$. Before US guided-catheterization, landmark technique was preferred for central vein cannulation. A number of studies have shown that US technique is superior to landmark technique ${ }^{(4-6,14-16)}$.
Central venous cannulation can be difficult in pediatric patients related to small size of the patients, and anatomical variations. Many factors affect the success of the procedure; the cannulation side may be also an important factor as well. As a conclusive remark, Hind et al. ${ }^{(9)}$ suggested that right jugular vein offers higher success rate for US-guided central venous cannulation. In support of this assumption, in the current study, right side was preferred for the first attempt unless any catheterization was performed previously.

Number of attempts is associated with higher complication rates. In a meta-analysis, Hind et al. ${ }^{(9)}$ concluded that complications are directly proportional to the number of attempts. Asheim et al. ${ }^{(17)}$ found that 40 out of 42 patients had successful US-guided cannulation at first attempt. Complication rates were highest with more than 3 cannulation attempts ${ }^{(17,18)}$. So cannulation attempts would be a meaningful outcome measure when evaluating the success rates of US guidance. US -guidance allowed the ability to visualize and avoid critical structures during central venous catheterization ${ }^{(19,20)}$. In fact, good visualization of the vein improves and facilitates the needle's insertion. In our practice, we used the midpoint of the probe as the insertion point, and stabilized the image of vein to the middle of the probe. We were able to achieve cannulation of internal jugular vein in $144(80 \%)$ out of 180 patients at the first attempt.

Using US guidance for central venous catheterization clearly improves the success of the procedure. Achievement of US-guided catheterization using percutaneous method was defined as success while catheterization with cutdown method as failure in the study. In the recent study, in only 9 patients cutdown was used, so the success rate was calculated as $95 \%$. In a large case series including 500 children, the success rate was $99.8 \%{ }^{(21)}$.

Only 2 out of 9 cutdowns performed by the residents which shows that US is really a helpful tool in catheterization even by less experienced performers. However there was no significant difference between residents and attending physicians, because attending physicians apparently performed higher number of cutdowns than residents. This condition could be explained by the fact that generally the specialists 
performed more difficult cases. However less experienced operators achieved higher success rates with the use of US ${ }^{(6)}$.

Other factors that may affect the success of catheterization could be gender, age and body weight of the patients. According to our results age and weight might account for the difference. Smaller age and weight seem to be negative factors during central venous catheterization.

As for the duration of catheterization, the attending physicians performed catheterizations quicker than the residents as expected. Expertise in US practice will reduce the number of attempts, duration of cannulation and complication rates ${ }^{(22)}$. In a recent study, as the experience of the performer increased, the time needed for cannulation decreased.

However, comparing US-guided technique with landmark technique would probably lead to achievement of more remarkable results, unfortunately negligence of this issue may be the limitation of this study. But we thought it would be unethical not to use US for central vein catheterization while owning an ultrasound for catheterization.

As a conclusion, ultrasound is a very useful tool for central venous catheterization in pediatric patients. Experience is an important factor for improving the success rates. Good visualization using ultrasound aids in the catheterization and increases the success rates at first attempt, which is directly related to lower rates of complications.

Ethics Committee Approval: Ankara University Faculty of Medicine Clinical Research Ethics Committee approval was obtained (2014 / 04-185-14).

\section{Conflict of Interest: None}

Funding: None

Informed Consent: The patients' consent were obtained.

\section{REFERENCES}

1. Casado-Flores J, Barja J, Martino R, Valdivielso A. Complications of central venous catheterization in critically ill children. Pediatr Crit Care Med. 2001;2:5762.

https://doi.org/10.1097/00130478-200101000-00012
2. Venkataraman ST, Thompson AE, Orr RA. Femoral vascular catheterization in critically ill infants and children. Clin Pediatr (Phila). 1997;36:311-9. https://doi.org/10.1177/000992289703600601

3. Schummer W, Schummer C, Rose N, Niesen WD, Sakka. Mechanical complications and malpositions of central venous cannulations by experienced operators. Int Care Med. 2007;33:1055-9. https://doi.org/10.1007/s00134-007-0560-z

4. Verghese ST, McGill WA, Patel RI, Sell J, Midgley F, Ruttimann U. Ultrasound-guided internal jugular venous cannulation in infants: a prospective comparison with the traditional palpation method. Anesthesiology. 1999;91:71-7. https://doi.org/10.1097/00000542-199907000-00013

5. Verghese ST, McGill WA, Patel RI, Sell J, Midgley F, Ruttimann U. Comparison of three techniques for internal jugular vein cannulation in infants. Ped Anesth. 2000;10:505-11.

https://doi.org/10.1046/j.1460-9592.2000.00554.x

6. Leyvi G, Taylor DG, Reith E, Wasnick JD. Utility of ultrasound-guided central venous cannulation in pediatric surgical patients: a clinical series. Ped Anesth. 2005; 15:953-8.

https://doi.org/10.1111/j.1460-9592.2005.01609.x

7. Alderson PJ, Burrows FA, Stemp LI, Holtby HM. Use of ultrasound to evaluate internal jugular vein anatomy and to facilitate central venous cannulation in paediatric patients. Br J Anaesth. 1993;70:145-8. https://doi.org/10.1093/bja/70.2.145

8. Mallinson C, Bennett J, Hodgson P, Petros AJ. Position of the internal jugular vein in children. A study of the anatomy using ultrasonography. Ped Anesth. 1999;9:111-4. https://doi.org/10.1046/j.1460-9592.1999.9220329.x

9. Hind D, Calvert N, McWilliams R, et al. Ultrasonic locating devices for central venous cannulation: metaanalysis. BMJ. 2003;327:361-4. https://doi.org/10.1136/bmj.327.7411.361

10. Morita M, Sasano $H$, Azami T, et al. A novel skintraction method is effective for realtime ultrasoundguided internal jugular vein catheterization in infants and neonates weighing less than 5 kilograms. Anesth Analg. 2009;109:754-9. https://doi.org/10.1213/ane.0b013e3181b01ae3

11. Shojania KG, Duncan BW, McDonald KM, Wachter RM, Markowitz AJ. Making health care safer: A critical analysis of patient safety practices. Evid Rep Technol Assess (Summ). 2001:i-x, 1-668.

12. Bailey PL, Glance LG, Eaton MP, Parshall B, Mclntosh S. A survey of the use of ultrasound during central venous catheterization. Anesth Analg. 2007;104:491-7. https://doi.org/10.1213/01.ane.0000255289.78333.c2

13. Denys BG, Uretsky BF, Reddy PS, Ruffner RJ, Sandhu JS, Breishlatt WM. An ultrasound method for safe and rapid central venous access. N Engl J Med. 1991;324:566. https://doi.org/10.1056/NEJM199102213240816

14. Hayashi Y, Uchida O, Takaki O, et al. Internal jugular vein catheterization in infants undergoing cardiovascular surgery: An analysis of the factors influencing successful catheterization. Anesth Analg. 1992;74:688-93. https://doi.org/10.1213/00000539-199205000-00012 15. Asheim P, Mostad U, Aadahl P. Ultrasound-guided 
central venous cannulation in infants and children. Acta Anaesthesiol Scand. 2002;46:390-2. https://doi.org/10.1034/j.1399-6576.2002.460410.x

16. Chuan WX, Wei W, Yu L. A randomized-controlled study of ultrasound prelocation vs anatomical landmark-guided cannulation of the internal jugular vein in infants and children. Pediatr Anesth. 2005;15:733-8.

https://doi.org/10.1111/j.1460-9592.2004.01547.x

17. Johnson EM, Saltzman DA, Suh G, Dahms RA, Leonard AS. Complications and risks of central venous catheter placement in children. Surgery. 1998;124:911-6. https://doi.org/10.1016/S0039-6060(98)70016-9

18. Bruzoni M, Slater BJ, Wall J, St Peter SD, Dutta S. A Prospective Randomized Trial of Ultrasound- vs Landmark-Guided Central Venous Access in the Pediatric Population J Am Coll Surg. 2013;216:939-43. https://doi.org/10.1016/j.jamcollsurg.2013.01.054

19. Froehlich CD, Rigby MR, Rosenberg ES, et al. Ultrasoundguided central venous catheter placement decreases complications and decreases placement attempts compared with the landmark technique in patients in a pediatric intensive care unit. Crit Care Med. 2009;37:1090-6.

https://doi.org/10.1097/CCM.0b013e31819b570e

20. Basford TJ, Poenaru D, Silva M. Comparison of delayed complications of central venous catheters placed surgically or radiologically in pediatric oncology patients. J Pediatr Surg. 2003;38:788-92. https://doi.org/10.1016/jpsu.2003.50168

21. Arul GS, Lewis N, Bromley P, Bennett J. Ultrasoundguided percutaneous insertion of Hickman lines in children. Prospective study of 500 consecutive procedures. J Ped Surg. 2009;44:1371-6. https://doi.org/10.1016/j.jpedsurg.2008.12.004

22. Al Sofyani K, Julia G, Abdulaziz B, Yves CJ, Sylvain R. Ultrasound guidance for central vascular access in the neonatal and pediatric intensive care unit. Saudi J Anaesth. 2012;6:120-4.

https://doi.org/10.4103/1658-354X.97023 